\title{
Synaptic Vesicle Protein 2 (SV2) does not hydrolyze ATP
}

\section{[version 1; peer review: 2 not approved]}

\author{
Jia Yao, Sandra M. Bajjalieh
}

Department of Pharmacology, University of Washington, Seattle, WA 98195, USA

\author{
V1 First published: 09 Oct 2013, 2:209 \\ https://doi.org/10.12688/f1000research.2-209.v1 \\ Latest published: 09 Oct 2013, 2:209 \\ https://doi.org/10.12688/f1000research.2-209.v1
}

\section{Abstract}

Synaptic vesicle protein 2 (SV2) is a transporter-like protein specifically expressed in endocrine cells and neurons, where it is localized to vesicles that undergo regulated secretion and plays an essential role in regulating neurotransmitter release. SV2 binds adenine nucleotides including ATP. Analysis of ATP transport revealed that SV2 is not an ATP transporter, nor does it affect ATP transport. As a further step toward understanding how ATP binding contributes to SV2 function, we investigated whether SV2 is an ATPase using an in vitro measure of ATPase activity. The study reported here indicates that SV2 does not have ATPase activity. Thus, binding to adenine nucleotides likely modulates other actions of SV2.

Keywords

SV2; nucleotide binding; ATP hydrolysis

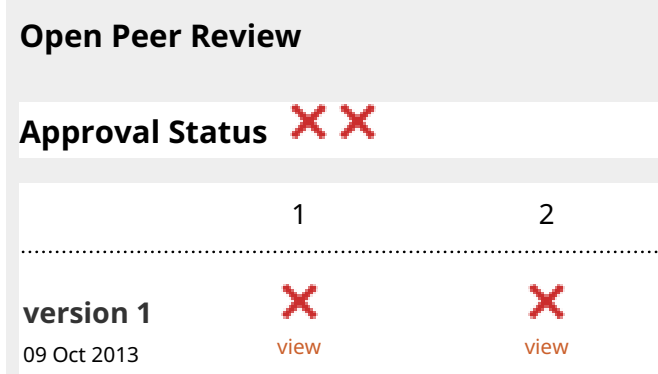

1. Yoshinori Moriyama, Okayama University, Okayama, Japan

2. Liangyi Chen, Peking University, Beijing, China

Any reports and responses or comments on the article can be found at the end of the article.

Corresponding author: Sandra M. Bajjalieh (bajjalie@uw.edu)

Competing interests: The authors have no conflicts of interests to disclose.

Grant information: This work was supported by National Institutes of Mental Health Grant R01 MH 059842 to SB.

The funders had no role in study design, data collection and analysis, decision to publish, or preparation of the manuscript.

Copyright: $\odot 2013$ Yao J and Bajjalieh SM. This is an open access article distributed under the terms of the Creative Commons

Attribution License, which permits unrestricted use, distribution, and reproduction in any medium, provided the original work is properly cited. Data associated with the article are available under the terms of the Creative Commons Zero "No rights reserved" data waiver (CCO 1.0 Public domain dedication).

How to cite this article: Yao J and Bajjalieh SM. Synaptic Vesicle Protein 2 (SV2) does not hydrolyze ATP [version 1; peer review: 2 not approved] F1000Research 2013, 2:209 https://doi.org/10.12688/f1000research.2-209.v1

First published: 09 Oct 2013, 2:209 https://doi.org/10.12688/f1000research.2-209.v1 


\section{Introduction}

Synaptic vesicle protein 2 (SV2) is a membrane protein expressed exclusively in neurons and endocrine cells where it is localized to vesicles that undergo regulated secretion ${ }^{1}$. Most mammals have three SV2 genes that encode three related proteins termed SV2A, $\mathrm{SV} 2 \mathrm{~B}$, and $\mathrm{SV} 2 \mathrm{C}^{2,3}$. Of these, SV2A is the most broadly expressed, and is present in nearly all neurons, whereas SV2C demonstrates the most restricted expression ${ }^{2,4,5}$. SV2 is essential for normal neurotransmission, as evidenced by epileptic seizures and premature death in SV2A or SV2A/B knockout mice ${ }^{6,7}$. Electrophysiological studies assessing neurotransmitter release in SV2 mutants indicate that $\mathrm{SV} 2$ acts as a positive modulator of calcium-dependent exocytosis $^{8-10}$. Neuron or endocrine cells lacking SV2 contain fewer vesicles competent for $\mathrm{Ca}^{2+}$-triggered secretion.

Despite our understanding of the physiological role of SV2, its molecular action remains unknown. We previously reported that SV2 binds adenine nucleotides including ATP ${ }^{11}$. Analysis of ATP transport by vesicles isolated from wild-type and SV2 mutants revealed that SV2 is not an ATP transporter, nor does it affect ATP transport $^{11}$. Thus it is not clear how ATP binding relates to SV2 function. One untested possibility is that SV2 is an enzyme that hydrolyzes ATP. To address this, we investigated whether SV2 has ATPase activity. Our results show that recombinant SV2A and SV2B do not hydrolyze ATP. Thus, binding to adenine nucleotides likely modulates other actions of SV2.

\section{Methods}

\section{Cell culture and transfection}

HEK293T cell (ATCC, Manassas, VA) culture and transfection with Lipofectamine ${ }^{\mathrm{TM}} 2000$ reagent (Invitrogen, Grand Island, $\mathrm{NY}$ ) were performed following the manufacturer's protocol ${ }^{11}$. To transfect one $15 \mathrm{~cm}$ plate of cells, $48 \mu \mathrm{g}$ of plasmid DNA and $96 \mu \mathrm{l}$ of Lipofectamine ${ }^{\mathrm{TM}} 2000$ reagent were mixed with $3 \mathrm{ml}$ of serum and antibiotic-free minimum essential media (MEM) (Invitrogen, Grand Island, NY). After incubation at room temperature for $5 \mathrm{~min}$, the DNA and Lipofectamine ${ }^{\mathrm{TM}} 2000$ reagent mixture was combined and allowed to sit for $20 \mathrm{~min}$ at room temperature. The transfection mixture was then added drop-wise to cells cultured in Dulbecco's modified Eagle's medium (DMEM) (Invitrogen, Grand Island, NY) supplemented with $10 \%$ fetal bovine serum. Cells were maintained at $37^{\circ} \mathrm{C}$ in a humidified incubator containing $5 \% \mathrm{CO}_{2}$. After $48 \mathrm{~h}$, medium was removed, cells were harvested, and rinsed with ice-cold phosphate-buffered saline (PBS) two times. Cell pellets were stored at $-80^{\circ} \mathrm{C}$ until use. Rat SV2A and SV2B were expressed with a C-terminal FLAG epitope (DYKDDDK) in the mammalian expression vector pIRES2-EGFP (Clontech, Mountain View, CA).

\section{Purification of SV2-FLAG protein}

Recombinant SV2A and SV2B -FLAG fusion proteins were purified using anti-FLAG M2 affinity agarose beads (Sigma; catalog number: A2220, mouse IgG1 monoclonal antibody) as described previously ${ }^{11}$. Briefly, transfected cells were harvested and washed with ice-cold phosphate-buffered saline (PBS). Cell extracts were made by adding extraction buffer $(150 \mathrm{mM}$ potassium acetate
(J.T. Baker, Phillipsburg, NJ), $10 \mathrm{mM}$ HEPES-KOH (pH 7.4) (Sigma, St. Louis, MO), 1\% Triton X-100 (Roche Applied Science, Indianapolis, IN), with $1 \times$ fresh protease inhibitor mixture added before each use (Roche Applied Science, Indianapolis, IN)) and incubated at $4^{\circ} \mathrm{C}$ for $1 \mathrm{~h}$. After extraction, insoluble material was removed by centrifugation (Beckman, Indianapolis IN) at 19,000 $\times \mathrm{g}$ for $20 \mathrm{~min}$. The resulting extract was mixed with pre-equilibrated anti-FLAG M2 agarose beads (Sigma, St. Louis, MO) and incubated with agitation at $4^{\circ} \mathrm{C}$ for $3-4 \mathrm{~h}$. The beads were washed four times with 20 volumes of extraction buffer. FLAG fusion protein was eluted from the beads with $3 \times$ FLAG peptide (Sigma, St. Louis, MO) in buffer containing $150 \mathrm{mM}$ potassium acetate, $10 \mathrm{mM}$ HEPES-KOH (pH 7.4) and 0.5\% Triton X-100. Final preparations were checked by silver staining (Thermo, Waltham, MA) of SDS polyacrylamide gels (Bio-Rad, Hercules, CA) and immunoblot with anti-SV2 (mouse monoclonal antibody against an epitope located on the N-terminus of SV2) ) $^{12}$ or anti-FLAG antibodies (Sigma, catalog number: F3165, mouse IgG1 monoclonal antibody). Protein concentration was determined by comparison to bovine serum albumin (BSA) (Fisher, Pittsburgh, PA) standards in PAGE gels. This method was used because the $3 \times$ FLAG peptide in the eluate will affect solution-based protein assays. BSA standards, ranging from 0.5 to $4 \mu \mathrm{g}$ were loaded on the same gel along with purified SV2-FLAG fusion proteins. Gels stained with coomassie blue were scanned with a Kodak Image Station 440CF (Kodak, Rochester, NY). Net intensities of protein bands were determined by Kodak Molecular Imaging software (Kodak, Rochester, NY) and protein concentration of recombinant SV2-FLAG was calculated according to BSA standards.

\section{ATP hydrolysis reaction}

ATP hydrolysis reactions were conducted at $25^{\circ} \mathrm{C}$ in a buffer consisting of $150 \mathrm{mM}$ potassium acetate, $10 \mathrm{mM}$ HEPES (pH 7.4), $2 \mathrm{mM}$ ATP, $3 \mathrm{MgCl}_{2}, 0.1 \%$ Triton X-100, $1 \mathrm{mM}$ DTT and 10-20 $\mu \mathrm{g} / \mathrm{ml}$ purified recombinant SV2-FLAG protein. The ATP hydrolysis reaction was set up on ice and recombinant SV2-FLAG protein was added last. Reaction mixtures were prepared on ice, and an aliquot of reaction was immediately withdrawn as the $0^{\circ} \mathrm{C}, 0 \mathrm{~min}$ sample. The reaction was shifted to $25^{\circ} \mathrm{C}$, and at designated intervals ( $1 \mathrm{~min}, 2 \mathrm{~min}$, $5 \mathrm{~min}$ and $10 \mathrm{~min}$ ), aliquots were removed from the reaction for analysis by the malachite green assay described below. Duplicates were assayed for each time point and the average value of the duplicates was used for quantification.

Commercially available calf intestinal alkaline phosphatase (CIP) (New England Biolabs, Ipswich, MA) was used as a positive control for the ATP hydrolysis reaction. As a negative control, an aliquot of CIP was heated at $95^{\circ} \mathrm{C}$ for 20 min to inactivate the enzyme.

\section{Malachite green assay for inorganic phosphate concentration}

To prepare the malachite green solution, one volume of $4.2 \%$ ammonium molybdate (Sigma, St. Louis, MO) in $4 \mathrm{M} \mathrm{HCl}$ was added to 3 volumes of $0.045 \%$ malachite green (Sigma, St. Louis, MO). The solution was stirred at room temperature for a minimum of 
30 min before being filtered through a $0.22 \mu \mathrm{m}$ membrane (Millipore, Billerica, MA). Malachite green solutions were kept at $4^{\circ} \mathrm{C}$ in the dark. Before each assay, $0.01 \%$ Tween- 20 was added to the malachite green solution.

$50 \mu \mathrm{l}$ aliquots of ATP hydrolysis reaction were added to $950 \mu \mathrm{l}$ of malachite green solution and color was allowed to develop for $20 \mathrm{~min}$ at room temperature. Absorbance at $620 \mathrm{~nm}$ was measured in a cuvette with the malachite green solution as a blank in a SmartSpec3000 spectrometer (Bio-Rad, Hercules, CA). A $0.02 \mathrm{mM} \mathrm{KH}_{2} \mathrm{PO}_{4}$ solution (Fisher, Pittsburgh, PA) was used as an inorganic phosphate standard. Phosphate release in ATP hydrolysis reactions was quantified by comparison to inorganic phosphate standards.

\section{Standard curve malachite green}

1 Data File

http://dx.doi.org/10.6084/m9.figshare. 811807

\section{Results and discussion}

To determine if SV2 is an ATPase we used a fast and reproducible method for measuring inorganic free phosphate released by ATP hydrolysis in aqueous solutions ${ }^{13,14}$. The assay is based on the change of absorbance at $620 \mathrm{~nm}$ after free phosphate forms a colored complex with molybdate/malachite green ${ }^{15}$. Figure 1 shows a standard

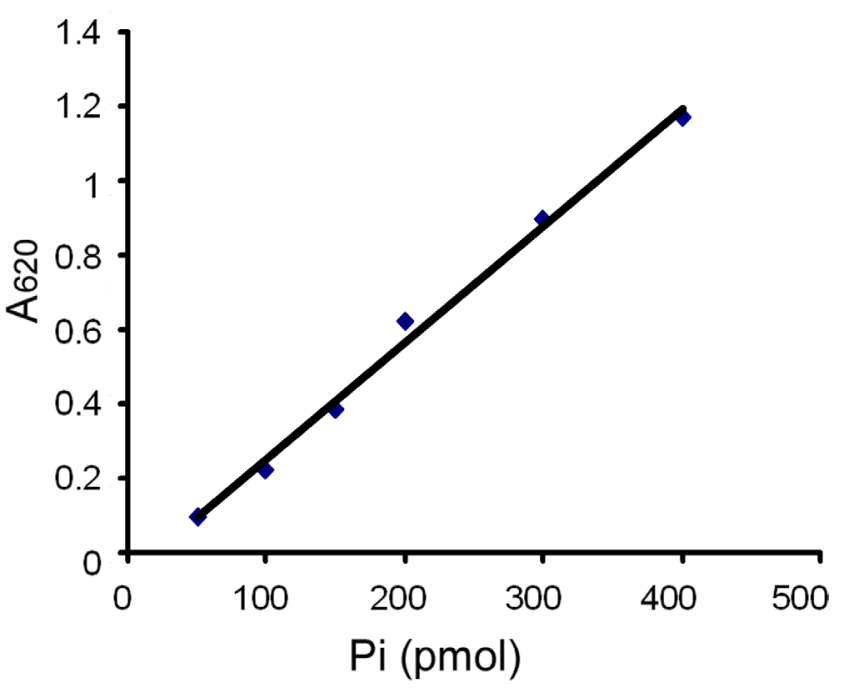

Figure 1. Standard curve of inorganic phosphate. Shown is a standard curve for inorganic phosphate $(\mathrm{Pi})$ in the malachite green assay. The data are representative of 5 independent experiments. Inorganic phosphate standards were prepared from $\mathrm{KH}_{2} \mathrm{PO}_{4}$. Each point represents the mean value of duplicate measurements. $50 \mu \mathrm{l}$ of standard solution containing different amounts of phosphate ( $\mathrm{Pi})$ was mixed with $950 \mu \mathrm{l}$ of malachite green solution and allowed to develop color at room temperature for $20 \mathrm{~min}$. The absorbance of each sample was measured at $620 \mathrm{~nm}$ and plotted against pmol of phosphate in the reaction. curve testing $0-400 \mathrm{pmol}$ of $\mathrm{KH}_{2} \mathrm{PO}_{4}$ in the reaction. It indicates that the cuvette-based assay produced a reliable linear standard curve.

As a positive control for phosphate production, we used $\mathrm{CIP}^{16}$, a type of alkaline phosphatase that catalyzes the hydrolysis of 5'-phosphate groups from various substrates, including 5'-nucleotides, RNA and DNA. Figure 2 shows that CIP catalyzed ATP hydrolysis in a time-dependent manner. Heat-inactivated CIP produced little activity that did not increase with time. These results attest to the effectiveness of the ATP hydrolysis reaction and the malachite green assay in this study.

To test for ATPase activity in SV2, we performed the assay with purified recombinant SV2. SV2A or SV2B fused to a FLAG epitope (for affinity purification) is the same preparation that was used to characterize ATP binding activity in vitro in our previous study ${ }^{11}$. In the malachite green assay neither SV2A nor SV2B produced ATP hydrolysis activity (Figure 3).

This result indicates that SV2 does not hydrolyze ATP. The concern that the FLAG epitope included at the carboxy terminus of recombinant SV2 used in these assays might affect activity is not likely given that SV2-EGFP fusion proteins can rescue normal neurotransmission in neurons from SV2 knockouts ${ }^{17}$. Together with previous studies reporting that SV2 is not likely to be an ATP transporter ${ }^{11}$, these findings exclude the possibility that SV2 affects ATP levels either by transport or hydrolysis. Therefore SV2 binding of ATP likely

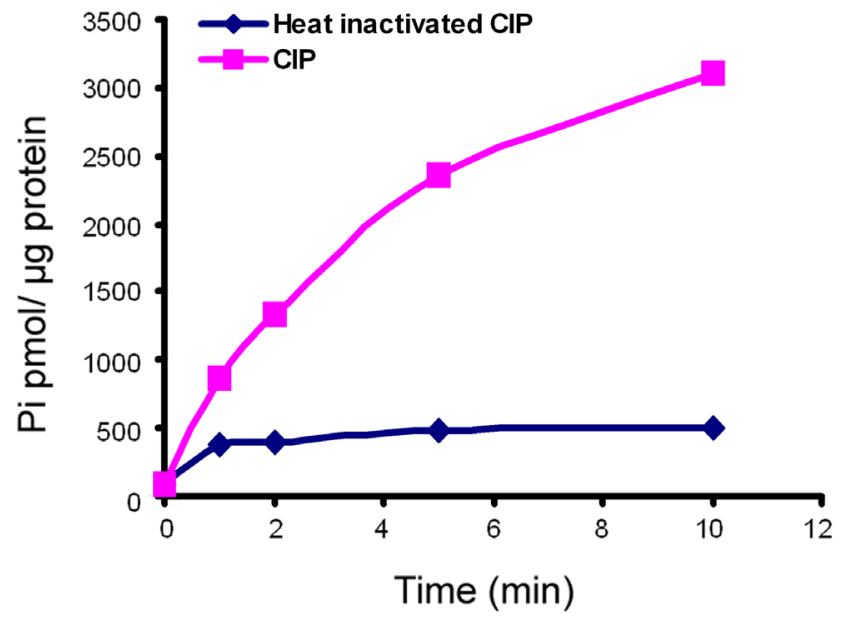

Figure 2. ATP hydrolysis by CIP. Shown is a time course of one calf intestinal alkaline phosphatase (CIP) reaction with ATP as a substrate. The data are representative of four independent experiments. The CIP reaction was carried out at $25^{\circ} \mathrm{C}$. At different time points, aliquots were withdrawn and subjected to the malachite green assay as described in Figure 1. Pi in each sample was quantified by comparing to the standard curve generated for inorganic phosphate. Each point represents the mean value of duplicate measurements. CIP exhibited time-dependent ATP hydrolysis activity while heat-inactivated CIP produce much lower activity that was not time-dependent. 

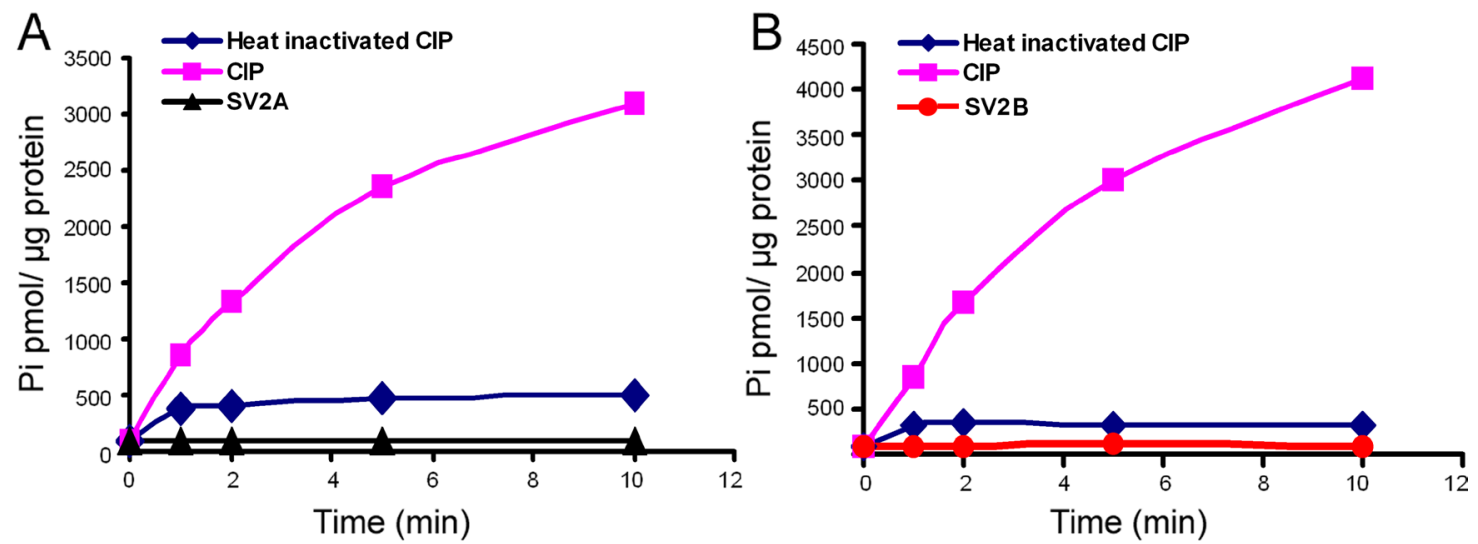

Figure 3. ATP hydrolysis reaction with recombinant SV2A and SV2B. Shown is a representative plot of ATP hydrolysis activity by recombinant SV2A (Panel A) or SV2B (Panel B). ATP hydrolysis reactions and the malachite green assay were performed as described under "Methods". The data represent two (SV2A) and three (SV2B) separate measures. For comparison, results of calf intestinal alkaline phosphatase (CIP) reactions run on the same day are included in the plots.

regulates its conformation or its molecular interactions, possibilities that suggest SV2 action is modulated by synaptic energy levels.

We previously show that a tyrosine-based endocytosis motif ( $\left.\mathrm{Y}^{46} \mathrm{SRF}\right)$ in the N-terminus of SV2 is required for its trafficking to synaptic vesicles, and that this motif mediates binding of multiple endocytosisrelated proteins ${ }^{18}$. Interestingly, one of the two ATP binding sites in SV2A (a.a. 58-104) is located in the same region ${ }^{11}$. This suggests a possible link between ATP binding and SV2 endocytosis.

\section{SV2AB and CIP data}

1 Data File

http://dx.doi.org/10.6084/m9.figshare.811808

\section{Abbreviations}

SV2, synaptic vesicle protein 2; CIP, calf intestinal alkaline phosphatase; ATP, adenosine-5'-triphosphate

\section{Author contributions}

JY and SB conceived and designed the study. JY performed the experiments and analyzed the data. JY and SB prepared the manuscript.

\section{Competing interests}

The authors have no conflicts of interests to disclose.

\section{Grant information}

This work was supported by National Institutes of Mental Health Grant R01 MH 059842 to SB.

The funders had no role in study design, data collection and analysis, decision to publish, or preparation of the manuscript.

\section{Acknowledgements}

We thank Dr Alex Merz for help with the malachite green assay and Mario Rosasco for editorial review of the manuscript.
1. Bajjalieh SM, Peterson $\mathrm{K}$, Shinghal R, et al.: SV2, a brain synaptic vesicle protein homologous to bacterial transporters. Science. 1992; 257(5074):

1271-1273.

PubMed Abstract | Publisher Full Text

2. Bajjalieh SM, Peterson K, Linial M, et al.: Brain contains two forms of synaptic vesicle protein 2. Proc Natl Acad Sci U S A. 1993; 90(6): 2150-2154. PubMed Abstract | Publisher Full Text | Free Full Text

3. Janz R, Sudhof TC: SV2C is a synaptic vesicle protein with an unusually restricted localization: anatomy of a synaptic vesicle protein family. Neuroscience. 1999; 94(4): 1279-1290. PubMed Abstract | Publisher Full Text

4. Dardou D, Dassesse D, Cuvelier L, et al.: Distribution of SV2C mRNA and protein expression in the mouse brain with a particular emphasis on the basal ganglia system. Brain Res. 2011; 1367: 130-145.

PubMed Abstract | Publisher Full Text

5. Bajjalieh SM, Frantz GD, Weimann JM, et al.: Differential expression of synaptic vesicle protein 2 (SV2) isoforms. J Neurosci. 1994; 14(9): 5223-5235.

PubMed Abstract

6. Janz R, Goda Y, Geppert M, et al.: SV2A and SV2B function as redundant Ca2+ regulators in neurotransmitter release. Neuron. 1999; 24(4): 1003-1016. PubMed Abstract | Publisher Full Text

7. Crowder KM, Gunther JM, Jones TA, et al:: Abnormal neurotransmission in mice lacking synaptic vesicle protein 2A (SV2A). Proc Natl Acad Sci U S A. 1999; 96(26): 15268-15273.

PubMed Abstract | Publisher Full Text | Free Full Text

8. Custer KL, Austin NS, Sullivan JM, et al:: Synaptic vesicle protein 2 enhances release probability at quiescent synapses. J Neurosci. 2006; 26(4): 1303-1313. PubMed Abstract | Publisher Full Text

9. Chang WP, Sudhof TC: SV2 renders primed synaptic vesicles competent for Ca2+-induced exocytosis. J Neurosci. 2009; 29(4): 883-897.

PubMed Abstract | Publisher Full Text | Free Full Text 
10. Wan QF, Zhou ZY, Thakur P, et al.: SV2 acts via presynaptic calcium to regulate neurotransmitter release. Neuron. 2010; 66(6): 884-895. PubMed Abstract | Publisher Full Text | Free Full Text

11. Yao J, Bajjalieh SM: Synaptic vesicle protein 2 binds adenine nucleotides. J Biol Chem. 2008; 283(30): 20628-20634.

PubMed Abstract | Publisher Full Text | Free Full Text

12. Buckley K, Kelly RB: Identification of a transmembrane glycoprotein specific for secretory vesicles of neural and endocrine cells. J Cell Biol. 1985; 100(4): 1284-1294.

PubMed Abstract | Publisher Full Text | Free Full Text

13. Maehama T, Taylor GS, Slama JT, et al:: A sensitive assay for phosphoinositide phosphatases. Anal Biochem. 2000; 279(2): 248-250. PubMed Abstract | Publisher Full Text

14. Taylor GS, Maehama T, Dixon JE: Myotubularin, a protein tyrosine phosphatase mutated in myotubular myopathy, dephosphorylates the lipid second messenger, phosphatidylinositol 3-phosphate. Proc Natl Acad Sci U S A.
2000; 97(16): 8910-8915.

PubMed Abstract | Publisher Full Text | Free Full Text

15. Lanzetta PA, Alvarez LJ, Reinach PS, et al.: An improved assay for nanomole amounts of inorganic phosphate. Anal Biochem. 1979; 100(1): 95-97.

PubMed Abstract | Publisher Full Text

16. Chen KT, Malo MS, Moss AK, et al.: Identification of specific targets for the gut mucosal defense factor intestinal alkaline phosphatase. Am J Physiol Gastrointest Liver Physiol. 2010; 299(2): G467-475 Gastrointest Liver Physiol. 2010; 299(2): G467-475.
PubMed Abstract | Publisher Full Text | Free Full Text

17. Nowack A, Yao J, Custer KL, et al.: SV2 regulates neurotransmitter release via multiple mechanisms. Am J Physiol Cell Physiol. 2010; 299(5): C960-967. PubMed Abstract | Publisher Full Text | Free Full Text

18. Yao J, Nowack A, Kensel-Hammes P, et al.: Cotrafficking of SV2 and synaptotagmin at the synapse. J Neurosci. 2010; 30(16): 5569-5578.

PubMed Abstract | Publisher Full Text | Free Full Text 


\section{Open Peer Review}

\section{Current Peer Review Status: $\mathrm{X} \times$}

\section{Version 1}

Reviewer Report 21 October 2013

https://doi.org/10.5256/f1000research.2173.r2050

(C) 2013 Chen L. This is an open access peer review report distributed under the terms of the Creative Commons Attribution License, which permits unrestricted use, distribution, and reproduction in any medium, provided the original work is properly cited.

Liangyi Chen

Institute of Molecular Medicine, Peking University, Beijing, China

SV2 is an important protein essential for normal synaptic transmission. However, its molecular action remains unclear. Previously these researchers have identified SV2 as a ATP binding protein. In this study, they proceed to test whether ATP binding to SV2 leads to the hydrolysis of ATP. However, the evidence presented here is not sufficient enough for such a strong assertion.

Main problem:

1. Although purified SV2 protein can bind ATP, it is unclear whether it has the correct structural conformation to mediate ATP hydrolysis. To prove such a method can work in vitro, control experiments with similar purified transmembrane proteins that catalyze ATP hydrolysis should be done.

2. Most importantly, it is unclear the local environment of SV2 proteins in vesicles in vivo, such as the concentration of ATP, $\mathrm{pH}$ and other factors. Therefore it will be ideal if the authors can measure ATP/ADP level in vivo in cells with overexpressed SV2 or not, using fluorescence indicators such as Perceval (Berg et al., Nat Methods. 2009; Tantama et al., Nat Commun. 2013).

Competing Interests: No competing interests were disclosed.

I confirm that I have read this submission and believe that I have an appropriate level of expertise to state that I do not consider it to be of an acceptable scientific standard, for reasons outlined above.

Reviewer Report 11 October 2013

https://doi.org/10.5256/f1000research.2173.r2051 
(C) 2013 Moriyama Y. This is an open access peer review report distributed under the terms of the Creative Commons Attribution License, which permits unrestricted use, distribution, and reproduction in any medium, provided the original work is properly cited.

\section{Yoshinori Moriyama}

Department of Membrane Biochemistry, Okayama University, Okayama, Japan

$\mathrm{SV} 2$ is a transporter-like synaptic vesicle membrane protein with unknown function. In the previous work, this group has shown that SV2 can bind ATP. In this paper, the group extended characterization of SV2 protein and found that SV2 does not hydrolyze ATP. This is important information about function of SV2. It is very difficult, however, to give any conclusion from negative results. Although I almost agree that SV2 does not possess ATP hydrolytic activity, the results shown here only mean that ATP hydrolytic activity by SV2 is under the detection limit under the conditions employed. The title and some sentences in the text are thus overstated. Further characterization on the SV2-dependent ATP hydrolytic activity, that is the effects of phospholipids and detergents, temperature and dose dependence on the ATP hydrolytic activity, will be required to support this conclusion. In addition, it is helpful for readers to evaluate the suitability of the assay system used in the paper if the authors use any kinds of ATPase as another positive control.

Furthermore, some important properties for enzymatic reaction by ATPase are lacking, some of which are as follows:

1. Indicate evidence that SV2A and B were purified.

2. Use of CIP as positive control is inappropriate. Please use ATPase such as ABC-type transporter for positive control.

3. Please show the effect of phospholipids on ATP hydrolysis by SV2.

4. Please show the dose dependence of SV2 protein.

5. Temperature dependence.

Competing Interests: No competing interests were disclosed.

I confirm that I have read this submission and believe that I have an appropriate level of expertise to state that I do not consider it to be of an acceptable scientific standard, for reasons outlined above. 
The benefits of publishing with F1000Research:

- Your article is published within days, with no editorial bias

- You can publish traditional articles, null/negative results, case reports, data notes and more

- The peer review process is transparent and collaborative

- Your article is indexed in PubMed after passing peer review

- Dedicated customer support at every stage

For pre-submission enquiries, contact research@f1000.com 